\title{
IDENTIFIKASI IKLIM MIKRO DAN KENYAMAN TERMAL RUANG TERBUKA HIJAU DI KENDARI
}

\author{
Santi ${ }^{1}$, Siti Belinda ${ }^{1 *}$, Hapsa Rianty ${ }^{1}$, Aspin ${ }^{1}$ \\ ${ }^{1}$ Jurusan Arsitektur, Fakultas Teknik, Universitas Halu Oleo, \\ Kampus Bumi Tridharma Andunohu, 93232 \\ *belinda_amri@uho.ac.id
}

\begin{abstract}
ABSTRAK. Fenomena UHI (Urban Heat Island) mengakibatkan suhu udara perkotaan menjadi tinggi, sehingga menurunkan kualitas lingkungan kota. Untuk dapat meningkatkan kualitas kota dan mengimbangi pertumbuhan kota, maka pemerintah menggalakkan pengembangan infrastruktur hijau perkotaan melalui pengembangan Ruang Terbuka Hijau (RTH). Kota Kendari memiliki beberapa ruang terbuka yang beberapa diantaranya merupakan pusat aktifitas dan interaksi masyarakat kota, diantaranya Taman Walikota dan Pelataran Tugu Religi. Penelitian ini merupakan penelitian deskriptif untuk mengetahui kondisi iklim mikro dan kenyamanan termal ruang terbuka. Data-data yang dikumpulkan berupa karakteristik dan nilai indikator iklim mikro yang meliputi suhu udara, kelembaban relatif, dan kecepatan angin pada sejumlah titik ukur pada siang hari. Data yang dikumpulkan dianalisis menggunakan uji Statistik Independent T Test untuk mengetahui perbedaan iklim mikro antara kedua lokasi dan analisis Temperature Humidity Index (THI) untuk mengetahui tingkat kenyamanannya. Hasil dari uji statistik menunjukkan tingkat perbedaan yang tidak sigifikan antara kedua lokasi, meliputi suhu udara (sig. $=0,283$ ); kelembaban relatif $($ sig. $=0,115)$; dan kecepatan angin (sig. $=0,105$ ). Sementara itu, melalui analisia THI menunjukkan nilai index tidak nyaman hampir terjadi pada keseluruhan titik ukur. Nilai THI tertinggi pada lokasi Taman Walikota terletak pada titik A5 $(\mathrm{THI}=31,9)$, yaitu pada daerah memiliki kecepatan angin rendah karena posisinya pada bagian tengah kawasan. Sedangkan pada lokasi pelataran Tugu Religi, nilai terendah THI diperoleh pada titik B9 $(\mathrm{THI}=33,12)$, yakni titik yang sebagian besar material permukaan lahannya berupa aspal.
\end{abstract}

Kata kunci: ruang terbuka, temperatur, angin, kelembaban relatif, Temperature Humidity Index

ABSTRACT. The UHI (Urban Heat Island) phenomenon affected urban air temperatures become high, which decreases the quality of the city environment. To be able to improve the quality of the city and to balance the growth of the city, the government promotes the development of urban green infrastructure through the development of Green Open Space (RTH). Kendari City has several open spaces, some of which are the center of the activities and interactions of urban communities, including the Taman Walikota and the Pelataran Tugu Religi. This research is a descriptive study to determine the microclimate conditions and thermal comfort of open spaces. The data collected is in the form of characteristics and values of microclimate indicators which include air temperature, relative humidity, and wind speed at some measuring points during the day. The collected data were analyzed using the Independent T-Test Statistic Test to determine the differences in microclimate between the two locations and the Temperature Humidity Index (THI) analysis to determine the level of comfort. The results of the statistical tests show a significant level of difference between the two locations, including air temperature (sig. = 0.283); relative humidity (sig. = 0.115); and wind speed (sig. $=0.105)$. Meanwhile, through THI analysis, the uncomfortable index value almost occurs at the whole measuring point. The highest THI value in the location of the Taman Walikota is located at point A5 $(T H I=31.9)$, which is in the area with low wind speed because of its position in the central part of the city. Whereas in the location of the Pelataran Tugu Religi, the lowest value of THI is obtained at point $B 9(T H I=33.12)$, which is the point where most of the surface material in the land is asphalt.

Keywords: open space, temperature, wind, relative humidity, Temperature Humidity Index

\section{PENDAHULUAN}

Perencanaan urban atau kawasan perkotaan menjadi hal populer selama beberapa dekade terakhir karena bertambahnya jumlah penduduk berdampak pada perubahan fisik lahan perkotaan. Kota Kendari seperti halnya kota-kota lainnya di Indonesia dan di dunia juga mengalami perubahan fungsi lahan. Hal ini terbukti menurut data BPS Kota Kendari [1], terjadi pertumbuhan area terbangun dalam kota yang meliputi kawasan permukiman, perkantoran, yang pada tahun 2013 berkisar 
13.018 Ha menjadi 13.969 Ha pada tahun 2016.

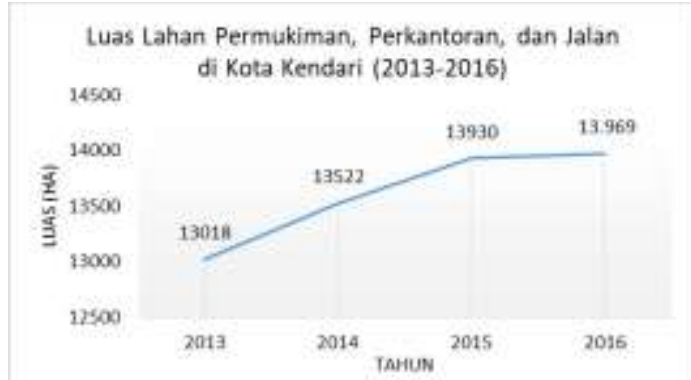

Gambar 1. Grafik pertumbuhan area terbangun di Kota Kendari

Sumber: BPS (2017) diolah

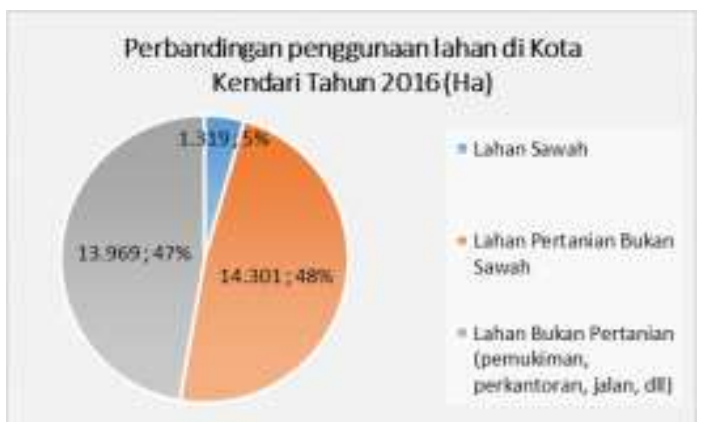

Gambar 2. Luas fungsi lahan Kota Kendari tahun 2016

Sumber: BPS (2017) diolah

Perbandingan luas lahan di Kota Kendari yang diusahakan atau terolah terlihat pada gambar, lahan untuk permukiman, perkantoran dan jalan mencapai $47 \%$ dari total 25.598 Ha dari total luas lahan. Perubahan fungsi lahan ini tentunya berdampak negatif bagi lingkungan. Salah satu faktor yang mengakibatkan terjadinya peningkatan temperatur perkotaan adalah semakin meningkatnya area terbangun dan berkurangnya lahan-lahan hutan dan vegetasi.

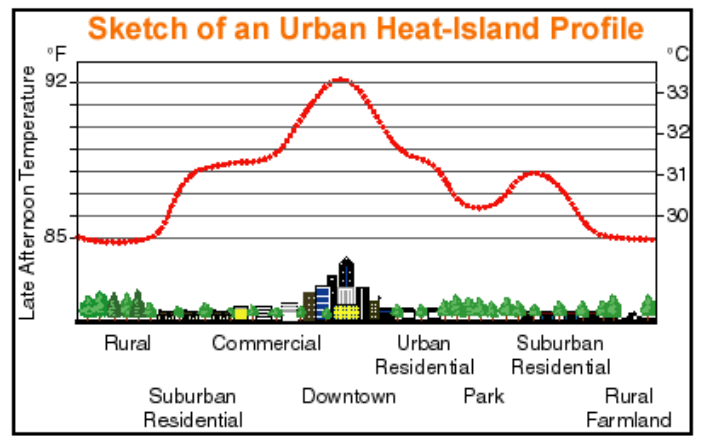

Gambar 3. Gambaran kondisi UHI

Sumber: Lawrence Berkeley National Laboratory, 2000

Istilah "urban heat island" diartikan sebagai perbedaan temperatur udara teramati antara lingkungan perkotaan dengan area pinggiran lainnya. Berdasarkan hasil pengamatan, terlihat bahwa temperatur udara pada pusat kota dapat mencapai $12^{\circ} \mathrm{C}$ lebih tinggi dengan daearah sekitarnya, seperti terlihat pada gambar 1 [2].

Menanggapi isu pemanasan global dan perubahan iklim yang ditandai dengan fenomena UHI, pemerintah Indonesia menerbitkan UU Nomor 26 Tahun 2007 tentang Penataan Ruang dan Permen PU No.05/PRT/M/2008 tentang Pedoman Penyediaan dan Pemanfaatan Ruang Terbuka Hijau di Kawasan Perkotaan, disebutkan bahwa pengertian Ruang Terbuka Hijau (RTH) adalah area memanjang/jalur dan atau mengelompok, yang penggunaannya lebih bersifat terbuka, tempat tumbuh tanaman, baik yang tumbuh tanaman secara alamiah maupun yang sengaja ditanam. Penyediaan RTH berdasarkan luas wilayah di perkotaan yakni diantaranya proporsi RTH pada wilayah perkotaan adalah sebesar minimal 30\% yang terdiri dari $20 \%$ ruang terbuka hijau publik dan $10 \%$ terdiri dari ruang terbuka hijau privat [3]. Selain berfungsi sebagai paru-paru kota, Ruang Terbuka Hijau juga seringkali dimanfaatkan oleh masyarakat perkotaan sebagai ruang untuk bersosialisasi dan beraktifitas lainnya.

Ruang terbuka identik dengan taman kota atau hutan kota, ruang ini merupakan ruang di dalam kota yang ditata untuk menciptakan keindahan, kenyamanan, keamanan, dan kesehatan bagi penggunanya. Selain itu, taman kota difungsikan sebagai paru-paru kota, pengendali iklim mikro, konservasi tanah dan air, dan habitat berbagai flora dan fauna. Zoer'aini Djamal (1997) dalam Sangkertadi [4] melalui penelitiannya menyimpulkan bahwa suhu udara di bawah naungan hutan kota dapat mencapai $3^{\circ} \mathrm{C}$ lebih rendah dibandingkan suhu sekitarnya.

Dalam perancangan ruang terbuka atau lansekap, terdapat komponen hard material atau perkerasan, soft material atau vegetasi, serta air dan elemen lainnya [5]. Setiap komponen lansekap mempengaruhi iklim mikro kawasan. Komponen iklim mikro berkaitan erat dengan faktor-faktor eksternal kenyamanan termal. Sementara itu, manusia sebagai pengguna ruang terbuka juga mempengaruhi kenyamanan termal dari segi internal. Aktivitas dan karakteristik manusia di ruang terbuka tentunya berbeda-beda. Faktor manusia dan lingkungan tentunya harus menjadi pertimbangan utama dalam perancangan ruang terbuka publik perkotaan. 
Menurut standar 55-1992 ASHRAE (American society of heating, refrigerating and airconditioning engineers), kenyamanan termal (thermal comfort) adalah keadaan pikiran manusia yang mengekspresikan kepuasan terhadap lingkungan sekitar. Menurut Karyono [6], kenyamanan dalam kaitannya dengan bangunan dapat didefinisikan sebagai suatu keadaan dimana dapat memberikan perasaan nyaman dan menyenangkan bagi penghuninya. Olgyay [7] mendefinisikan zona kenyamanan sebagai suatu zona dimana manusia dapat mereduksi tenaga yang harus dikeluarkan dari tubuh dalam mengadaptasikan dirinya terhadap lingkungan sekitarnya.

Microclimate atau iklim mikro adalah kondisi iklim pada suatu ruang yang sangat terbatas sampai batas kurang lebih setinggi dua meter dari permukaan tanah. Iklim mikro merupakan iklim dalam ruang kecil yang dipengaruhi oleh beberapa faktor, seperti hutan, rawa, danau, dan aktivitas manusia. Pengaruh lingkungan terhadap iklim mikro misalnya terhadap suhu udara, suhu tanah, kecepatan arah angin, intensitas penyinaran yang diterima oleh suatu permukaan, dan kelembaban udara [8].

Lippsmeier mengemukakan bahwa pada umumnya tergapat tiga komponen iklim yang menjadi parameter penentuan kenyamanan termal [9], yakni:

a. Temperatur Udara

Berdasarkan penelitian Mom dan Wiesebrom tahun 1940, kriteria nyaman berdasarkan suhu udara untuk penduduk asli Indonesia terbagi atas tiga yakni: 1) sejuk nyaman, dengan suhu $20,5^{\circ} \mathrm{C}$ $22,8^{\circ} \mathrm{C}$ (TE); nyaman optimal dengan suhu $22,8^{\circ} \mathrm{C}-25,8^{\circ} \mathrm{C}$ (TE); dan hangat nyaman dengan suhu $25,8^{\circ} \mathrm{C}-27,1^{\circ} \mathrm{C}$ (TE) [10].

b. Kelembaban Udara

Kelembaban udara merupakan jumlah kadar air dalam udara yang dinyatakan dalan persen. Kelembaban udara yang nikmat untuk tubuh berkisar antara $40 \%$ $70 \%$. Sementara itu, pada daerah tertentu, misalnya di tempat-tempat seperti di tepi pantai, kelembaban berkisar $80 \%-98 \%$. Oleh itu diperlukan pada daerah dengan kelembaban tinggi memerlukan tindakan agar penguapan dipercepat. [11].

c. Angin

Angin merupakan udara yang bergerak. Kecepatan angin untuk kenyamanan dalam ruangan terdapat pada batas-batas kecepatan antara 0,1 m/detik sampai dengan $0,5 \mathrm{~m} /$ detik., apabila melebihi batas tersebut (diatas/dibawah) maka sensasi dikatakan tidak nyaman (netral) [9][11].

Berdasarkan beberapa penjelasan sebelumnya, maka dapat dirumuskan tujuan dari penelitian ini adalah untuk mengetahui pengaruh penataan Ruang Terbuka Hijau (RTH) publik terhadap iklim mikro dan tingkat kenyamanan termal pada beberapa ruang terbuka di Kota Kendari. Penelitian ini diharapkan memberikan kontribusi serta sebagai bahan pertimbangan dalam merencanakan penataan kota ke depannya, sehingga tercipta kota yang berkelanjutan untuk kenyamanan manusia dan keberlangsungan lingkungan perkotaan.

\section{METODE PENELITIAN}

\section{Lokasi dan Waktu Penelitian}

Penelitian dilakukan di Kota Kendari. Wilayah Kota Kendari dengan ibukotanya Kendari dan sekaligus juga sebagai ibukota Provinsi Sulawesi Tenggara secara astronomis terletak dibagian selatan garis khatulistiwa berada diantara $3^{0} 54^{\prime} 30^{\prime \prime}-4^{0} 3{ }^{\prime} 11^{\prime \prime}$ Lintang Selatan dan membentang dari Barat ke Timur diantara $122^{0} 23^{`}-122^{0} 39^{`}$ Bujur Timur. Sebagaimana daerah-daerah lain di Indonesia, Kota Kendari hanya mengenal dua musim yakni musim kemarau dan musim hujan. merupakan daerah dengan suhu tropis. Menurut data yang diperoleh dari Stasiun Badan Meteorologi, Klimatologi dan Geofisika Stasiun Maritim Kendari tahun 2016 suhu udara maksimum berada di angka $33{ }^{\circ} \mathrm{C}$ dan suhu udara minimum yakni $23,1{ }^{\circ} \mathrm{C}$, kelembaban udara rata-rata sebesar $83,67 \%$. Sementara itu, ratarata kecepatan angin pada tahun yang sama mencapai 4,86 knot.

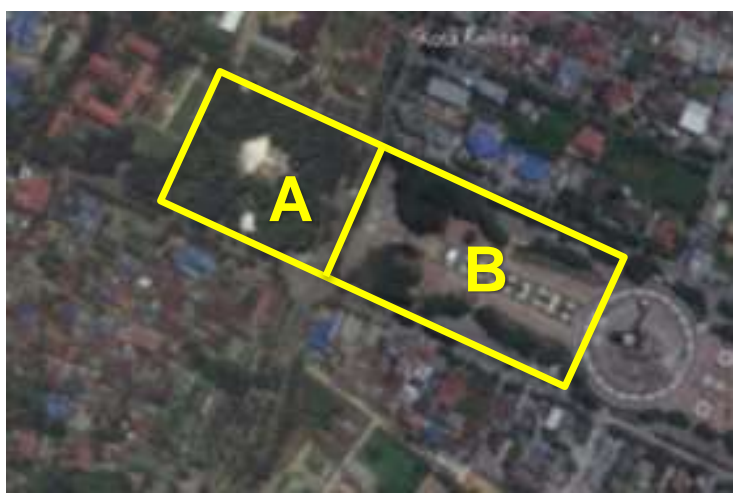

Gambar 4. Batasan lokasi penelitian, a) Taman Walikota; b) Pelataran Tugu Religi

Sumber: gambar diolah dari Google Earth

Lokasi penelitian mengambil objek pada dua buah kawasan Ruang Terbuka Hijau (RTH) di 
Kota Kendari, yakni Taman Walikota dan pelataran Tugu Religi Sultra (gambar 4). Walaupun letaknya saling bersebelahan, pengelolaan kedua RTH ini berbeda. Taman Walikota dikelola oleh pemerintah Kota Kendari, sedangkan pelataran Tugu Religi Sultra dikelola oleh pemerintah Provinsi Sulawesi Tenggara. Kedua RTH terletak tepat di jantung kota Kendari, menjadikan kedua lokasi ini menjadi tempat favorit warga Kota Kendari untuk beraktifitas dan bersosialisasi.

Berdasarkan pengolahan data dari Google Earth, luas kawasan Taman Walikota mencapai $\pm 6 \mathrm{Ha}$. Sementara itu kawasan pelataran Tugu Religi Sultra dibatasi hingga luas $\pm 7 \mathrm{Ha}$, hal ini dikarenakan beberapa area di kawasan ini telah berfungsi sebagai jalan raya yang sering dilalui oleh kendaraan bermotor dan tidak digunakan oleh masyarakat untuk beraktifitas ringan seperti berolahraga dan bersantai, sehingga sebagian area tersebut tidak terhitung ke dalam luasan area yang diteliti.

\section{Tahapan Penelitian}

Penelitian merupakan penelitian deskriptif. Data yang dibutuhkan terdiri atas data komposisi RTH dan iklim mikro kawasan. Penentuan titik sampel untuk sebaran pengambilan data iklim mikro kawasan ditentukan menjadi sembilan titik pada RTH Taman Walikota dan sepuluh titik pada RTH pelataran Tugu Religi Sultra (Gambar 5). Data pengamatan RTH yang diperlukan diantaranya 1) perletakan vegetasi; 2) jenis tutupan permukaan tanah. Selain data komposisi lansekap ruang terbuka, diperlukan juga data parameter iklim mikro berupa: 1) temperatur ambien; 2) kelembaban relatif; 3) kecepatan angin. Pengumpulan data parameter iklim mikro menggunakan beberapa alat ukur diantaranya Lutron ME-9000 Environment 9in1 dan Multi Function Environment Meter CEM DT-8820.

Pengambilan data iklim mikro dilakukan pada siang hari pada pukul 12.30 hingga pukul 14.00. Penentuan waktu pengambilan data sengaja dilakukan pada kondisi tengah hari untuk mendapatkan nilai parameter iklim mikro yang maksimal karena nilai radiasi matahari tertinggi terjadi setelah tengah hari menjelang sore hari. Pengambilan data iklim mikro dilakukan selama 5 hari pada bulan September 2017, pada kondisi cuaca cerah.
Pemilihan pengambilan data pada bulan September kerena berdasarkan pola iklim beberapa tahun terakhir di Kota Kendari, bulan September merupakan salah satu bulan panas.

Selanjutnya, data yang diperoleh kemudian dianalisis secara deskriptif berdasarkan variabel data yang dikumpulkan. Data komposisi RTH dianalisis dengan melihat kondisi penataan elemen lansekap per titik ukur dan secara keseluruhan, termasuk penggunaan material tutupan tanah. Sementara itu, data iklim mikro dianalisis dengan mengumpulkan data-data ke dalam tabel untuk melihat rata-rata nilai variabel iklim mikro. Perbedaan antara rata-rata suhu udara, kelembaban relatif, dan kecepatan angin pada setiap titik ukur di kedua lokasi dianalisis menggunakan uji statistik Correlate Independent T Test.

Ada berbagai formula yang dapat digunakan sebagai referensi untuk menghitung kenyamanan termis manusia di suatu lingkungan iklim mikro. Salah satunya adalah formula Temperatur Humidity Index (THI). Metode THI pertama kali dikemukakan oleh Thom, selanjutnya dimodifikasi oleh Nieuwolt untuk kondisi iklim tropis [12][13]. THI digunakan untuk menujukkan tingkat kenyamanan termal di suatu daerah yang dipengaruhi oleh faktor temperatur dan kelembaban relatif [14]. Adapun rumus yang digunakan untuk menentukan THI adalah sebagai berikut:

$$
T H I=0.8 T+\frac{R H x T}{500}
$$

Dimana:

$\begin{array}{ll}\text { THI } & : \text { Temperature Humidity Index } \\ \text { T } & : \text { Suhu udara }\left({ }^{\circ} \mathrm{C}\right) \\ \mathrm{RH} & : \text { Kelembaban Relatif }(\%)\end{array}$

Adapun kriteria kenyamanan thermal berdasarkan THI pada iklim tropis di Indonesia terbagi atas 3 kategori yakni nyaman, tidak nyaman, dan sangat tidak nyaman [14][15].

Tabel 1. Kriteria THI

\begin{tabular}{cc}
\hline Nilai THI & Kriteria kenyamanan \\
\hline$<29$ & Nyaman \\
\hline $29-30,5$ & Tidak nyaman \\
\hline$>30,5$ & Sangat tidak nyaman \\
\hline Sumber: Frick \& Suskiyatno (1998)
\end{tabular}

Sumber: Frick \& Suskiyatno (1998) 


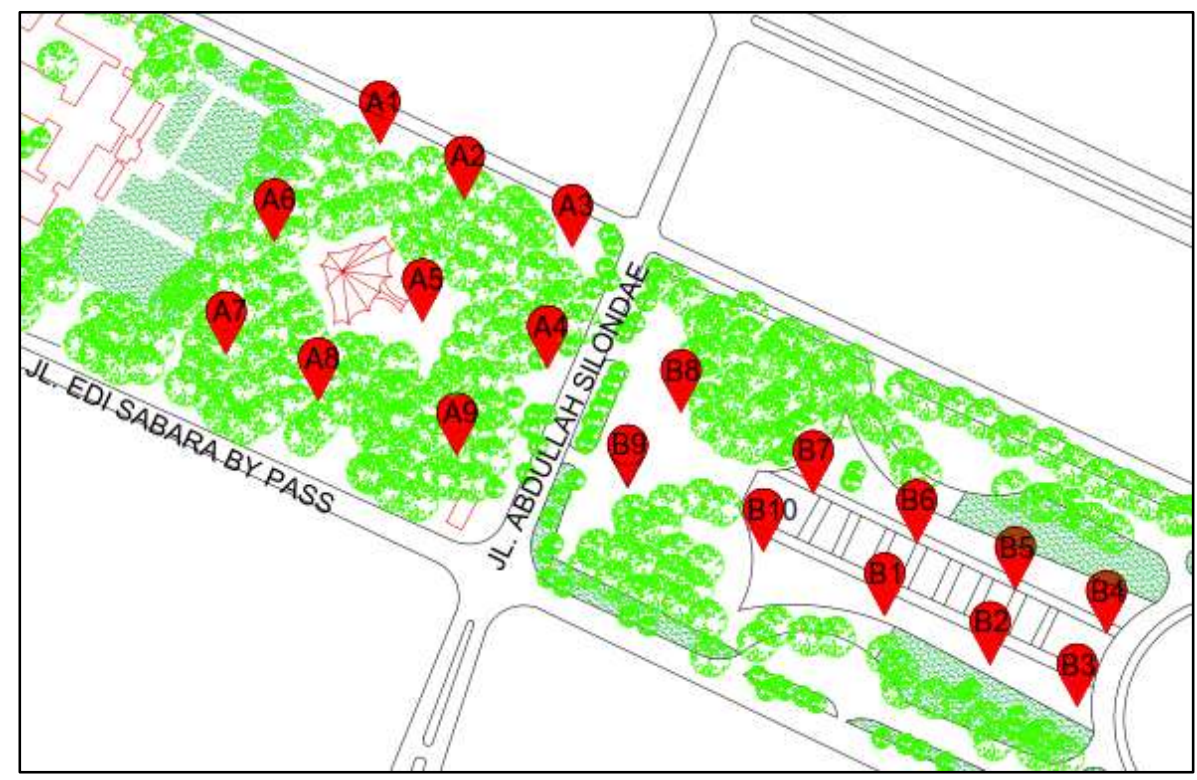

Gambar 5. Titik pengambilan data iklim mikro RTH

\section{HASIL DAN PEMBAHASAN}

\section{Area Taman Walikota}

Lokasi ini berbatasan langsung dengan lapangan Upacara kantor Walikota Kendari. Aktifitas yang sering dilakukan warga di tempat ini adalah berolah raga dan bersantai. Untuk mendukung aktifitas berolahraga, di dalam taman terdapat fasilitas jogging track yang dibuat mengelilingi taman dan tersedia pula berbagai permainan anak. Jogging track selebar 2 meter merupakan area perkerasan yang ditutupi oleh tegel non slip berwarna maroon dan putih. Selain itu juga terdapat bagian perkerasan pada jogging track yang dilapisi kerikil guna menyeimbangi efek licin dari penggunaan tegel. selanjutnya, terdapat tugu, kolam dan dua buah bangunan berstruktur tenda untuk tempat beristirahat pengunjung. Sekitar area tersebut permukaan lantainya dilapisi dengan tegel anti slip. Selain bagian-bagian tersebut di atas. Keseluruhan permukaan lahan masih dibiarkan tertutup tanah dan rumput secara alami.

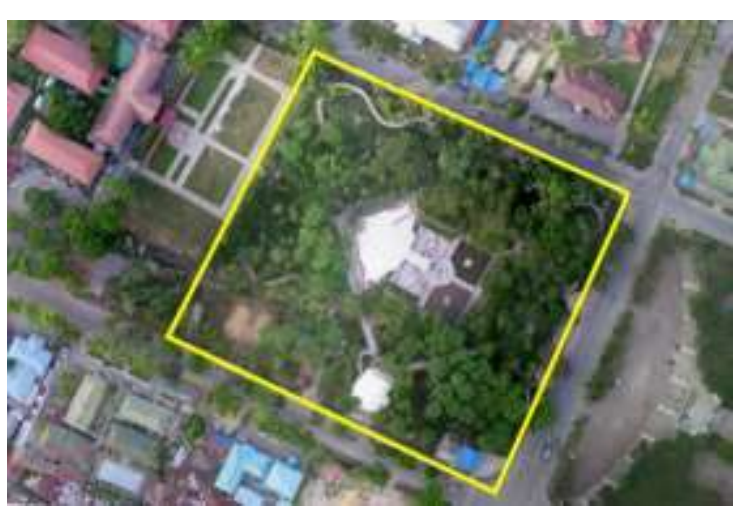

Gambar 6. Aerial view kawasan Taman Walikota
Pola vegetasi pada Taman Walikota mengelilingi kawasan taman. Pohon-pohon da perdu dibiarkan tumbuh di sekeliling taman sebagai pembatas dengan area jalan di sekelilingnya. Penanaman vegetasi dengan tajuk lebar dan tingkat kerapatan tinggi khususnya pada bagian yang berbatasan dengan J. Abd. Silondae tidak memungkinkan sinar matahari masuk ke dalam tapak. Bagian tengah tapak dibiarkan terbuka tanpa vegetasi karena terdapat bangunan tenda terbuka. Kondisi ini membuat bagian tengah tapak lebih terang dibandingkan area lainnya. Akan tetapi angin tidak dapat berhembus dengan baik khususnya pada bagian tengah area Taman Walikota karena tingkat kerapatan vegetasi menghambat aliran angin masuk dari luar kawasan. Radiasi matahari juga sulit masuk pada daerah yang memiliki kerapatan tajuk pohon yang tinggi. Berdasarkan ketersediaan vegetasi, daerah bervegetasi berkisar $78 \%$ dari total lahan $\pm 6,6 \mathrm{Ha}$.

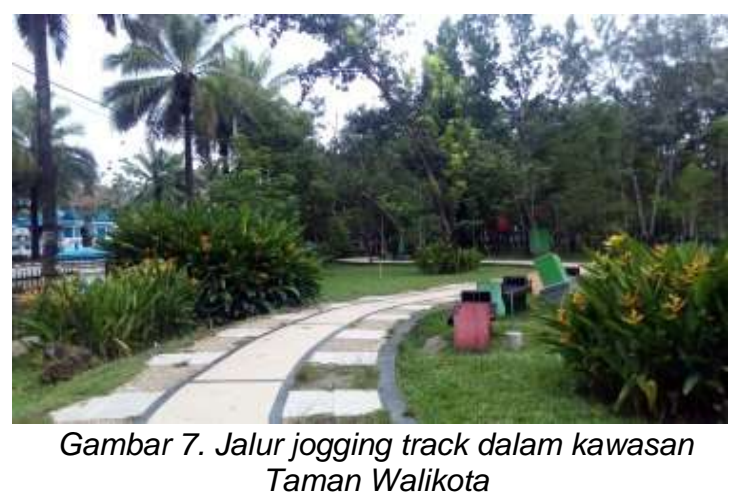


Tabel 2. penggunaan material area Taman Walikota

\begin{tabular}{ccccccc}
\hline Ttk & 1 & 2 & 3 & 4 & 5 & 6 \\
\hline$A 1$ & $x$ & $x$ & $x$ & - & $x x x$ & - \\
$A 2$ & $x$ & $x x$ & $x x$ & $x x x$ & - & - \\
$A 3$ & $x$ & $x$ & $x$ & - & $x x x$ & - \\
$A 4$ & $x$ & $x$ & $x x$ & - & $x x x$ & - \\
$A 5$ & $x$ & $x x$ & - & - & - & $x x x$ \\
$A 6$ & $x$ & $x x$ & $x x$ & $x x x$ & - & - \\
$A 7$ & $x$ & $x$ & $x$ & $x x x$ & $x x x$ & - \\
$A 8$ & $x$ & $x$ & $x x x$ & $x x x$ & $x x$ & $x x$ \\
$A 9$ & $x$ & $x$ & $x x$ & $x x x$ & $x x x$ & - \\
Keterangan material: & $1=$ tegel hitam; & 2=tegel putih; \\
3=perkerasan; 4=tanah; $5=$ =rumput; $6=$ =air; & \\
Keterangan komposisi material: $x=$ medikit; $x x=$ sedang; \\
xxx=banyak.
\end{tabular}

Dari pengolahan foto aerial view pada gambar 6 terlihat penggunaan material pada kawasan Taman Walikota didominasi oleh elemen alami. Tabel 2 menunjukkan data penggunaan material penutup permukaan tanah di sekitar titik-titik ukur. Dari tabel terlihat bahwa pemanfaatan elemen rumput dan tanah merupakan penggunaan terbanyak. Tegel berwarna hitam dan putih sebagian besar digunakan pada area jogging track dan bangunan tenda, akan tetapi dalam luasan yang sedikit. Terdapat elemen air si sekitar titik A5 karena terdapat kolam yang mengelilingi area monumen di bagian tengah taman.

\begin{tabular}{cccc}
\multicolumn{4}{c}{ Tabel 3. Indikator iklim mikro area Taman Walikota } \\
\hline $\begin{array}{c}\text { Titik } \\
\text { ukur }\end{array}$ & $\begin{array}{c}\text { Kec. angin } \\
(\mathrm{m} / \mathrm{s})\end{array}$ & $\begin{array}{c}\text { Tempera } \\
\text {-tur }(\mathrm{C})\end{array}$ & $\begin{array}{c}\text { Kelemba- } \\
\text { ban }(\% R h)\end{array}$ \\
\hline A1 & 0,34 & 34,02 & 51,68 \\
A2 & 0,90 & 33,36 & 50,04 \\
A3 & 0,82 & 33,36 & 51,36 \\
A4 & 1,06 & 33,90 & 48,02 \\
$A 5$ & 0,40 & 35,60 & 48,04 \\
$A 6$ & 0,46 & 33,92 & 48,90 \\
A7 & 0,60 & 32,06 & 48,40 \\
A8 & 0,40 & 33,06 & 50,32 \\
A9 & 0,34 & 32,98 & 51,18 \\
\hline
\end{tabular}

Terdapat 9 titik pengambilan data pada kawasan Taman Walikota. Hasil rata-rata pengukuran terhadap tiga indikator iklim mikro selama beberapa hari terlihat pada tabel 3 dan gambar 8 . Pada gambar 8 terlihat parameter iklim mikro beserta standar kenyamanan pada setiap parameternya. Pada parameter kecepatan angin, kecepatan angin tertinggi terdapat pada titik A4 yakni 1,06, dan terendah pada titik A5 dan A8. Berdasarkan standar kecepatan angin untuk kondisi nyaman sebaiknya berada pada rentang $0,1 \mathrm{~m} / \mathrm{s}-0,5$ $\mathrm{m} / \mathrm{s}$. Dari kesembilan titik ukur di lokasi Taman Walikota, terdapat 5 titik yang masuk ke dalam rentang tersebut yakni titik $\mathrm{A} 1, \mathrm{~A} 5, \mathrm{~A} 6, \mathrm{~A} 7, \mathrm{~A} 8$, A9. Kecepatan angin pada titik A4 cenderung cukup tinggi karea kondisi area tersebut cukup terbuka dan berbatasan langsung dengan jalan raya. Tidak ada buffer atau penghalang terhadap angin yang bertiup dari arah jalan raya.

Sementara itu, pada indikator kelembaban relatif, keseluruhan titik ukur berada batas batas ambang nyaman yakni $48 \%-51 \%$. Pada Indikator temperatur udara, secara keseluruhan titik yang terpantau berada di atas suhu $32^{\circ} \mathrm{C}$. Tidak ada satu pun titik ukur yang berada pada kondisi nyaman. Suhu udara tertinggi tercatat terjadi pada titik A5, yakni titik yang terletak di tengah-tengah taman. Salah satu hal yang mempengaruhi kondisi ini karena tidak adanya vegetasi di sekitar titik tersebut hingga radius 6 meter. Hal ini meyebabkan tidak ada filter terhadap radiasi matahari pada area tersebut.

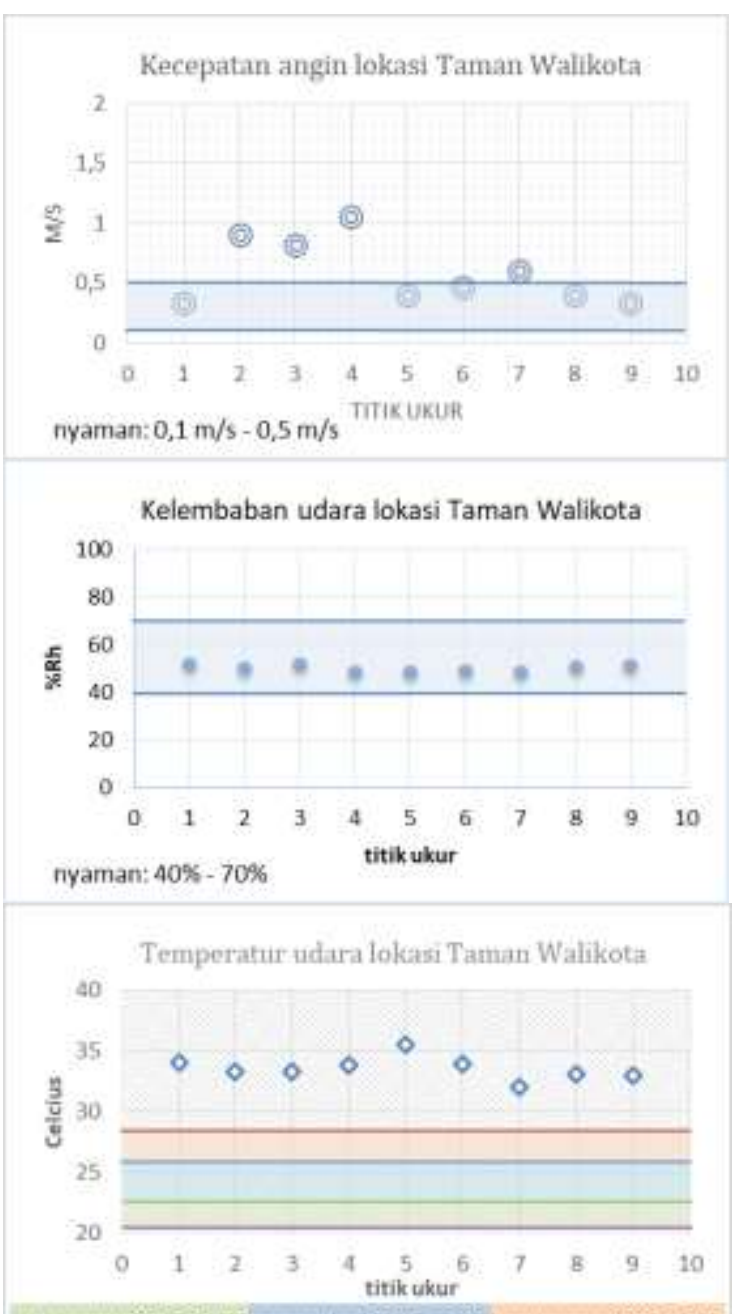

Gambar 8. Grafik nilai parameter iklim mikro lokas Taman Walikota

\section{Area Tugu Religi}

Area pelataran Tugu Religi atau yang lebih dikenal dengan nama Area pelataran Ex MTQ merupakan kawasan landmark Kota Kendari karena di lokasi ini terdapat Tugu yang menjadi icon Kota Kendari setinggi 99 meter. 
Aktifitas yang sering terjadi di kawasan ini yakni sebagai tempat berkumpulnya masyarakat saat diadakan kegiatan berskala besar dengan massa besar pula. Sebagian besar tutupan material pada kawasan ini adalah aspal dan perkerasan. Di sisi utara, selatan, dan barat terdapat tempat parkir kendaraan, sedangkan di sisi timur terdapat bangunan Tugu. Material penutup permukaan tapak sebagian besar merupakan material buatan misalnya aspal, perkerasan, tegel, dan paving block. Material aspal mendominasi area parkir kendaraan, sedangkan bagian tengah pelataran permukaan tanah ditutupi dengan material perkerasan dan keramik/tegel.

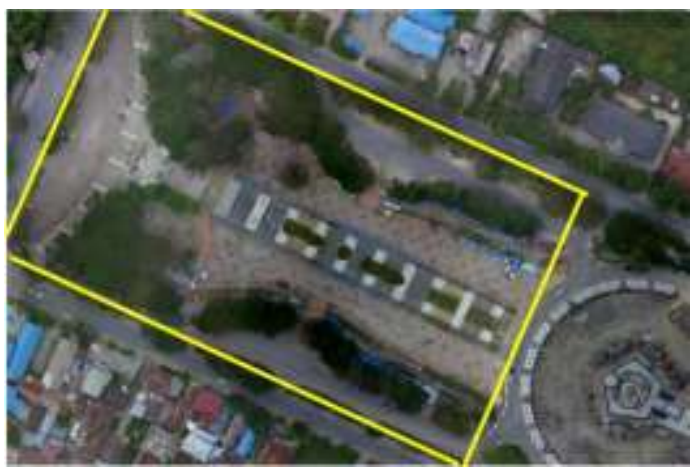

Gambar 9. Aerial view Kawasan Tugu Religi

Vegetasi umumnya berada pada bagian tepi kawasan sepanjang jalan arah utara-selatan dan area parkir. di bagian tengah tidak terdapat pohon-pohon tinggi, hanya beberapa titik saja yang ditananami tananaman perdu. Berdasarkan pembacaan gambar aerial view, terhitung jumlah area yang berupa vegetasi berkisar $48 \%$ dari total lahan yang teramati yakni 7,1 $\mathrm{Ha}$. Pada sisi barat yang berbatasan langsung dengan Jl. Abd. Silondae, jumlah vegetasi sangat sedikit dan dengan tajuk yang tidak rimbun. Hal yang serupa juga terdapat pada bagian yang berbatasan dengan Tugu, dimana tidak terdapat vegetasi yang ada hanya jalan raya yang melingkari Tugu. Kondisi ini mengakibatkan radiasi matahari pada bagian tengah sepangang sisi barattimur tidak memiliki penghalang. Angin pun dapat masuk melalui arah barat ataupun timur karea kondisinya yang terbuka dan minim vegetasi.

Seperti yang telah dikemukakan sebelumnya, kawasan pelataran tugu Religi didominasi oleh material buatan yakni elemen hard material. Penggunaan elemen ini dikarenakan fungsi utama areal ini adalah sebagai tempat didakannya kegiatan-kegiatan besar berskala lokal dan nasional, misalnya kegiatan pameran pembangunan. Terdapat 8 jenis material yang digunakan, dan sebagian besar hampir sama dengan material yang digunakan di kawasan taman walikota. Material paving block digunakan hampir di seluruh bagian di sekitar titik ukur dan dalam luasan yang besar (tabel 4).

Tabel 4. Penggunaan Material Area Pelataran Tugu Religi Sultra

\begin{tabular}{ccccccccc}
\hline \multirow{2}{*}{ Ttk } & \multicolumn{10}{c}{ Material } \\
& 1 & 2 & 3 & 4 & 5 & 6 & 7 & 8 \\
\hline$B 1$ & $x$ & $x$ & $x x x$ & $x x x$ & - & - & - & - \\
$B 2$ & $x$ & $x$ & $x x x$ & $x x x$ & - & - & - & - \\
$B 3$ & $x$ & $x$ & $x x$ & - & $x x x$ & - & - & - \\
$B 4$ & - & $x$ & $x x$ & $x x$ & $x x$ & $x x$ & - & - \\
$B 5$ & $x$ & - & - & $x x x$ & - & - & $x x$ & $x x x$ \\
$B 6$ & $x$ & - & - & $x x x$ & - & - & $x x$ & $x x x$ \\
$B 7$ & $x$ & $x$ & - & $x x x$ & - & - & $x x$ & - \\
$B 8$ & - & - & $x x$ & - & $x x x$ & - & $x x$ & - \\
$B 9$ & - & - & $x x$ & - & $x x x$ & - & $x x$ & - \\
B10 & $x$ & $x$ & $x x$ & $x x x$ & - & - & - & - \\
\hline
\end{tabular}

Keterangan material: 1=tegel maroon; 2=tegel hitam; $3=$ perkerasan; $4=$ paving block; $5=$ aspal; $6=$ tanah; $7=$ tegel putih; 8=rumput.

Keterangan komposisi material: $\mathrm{x}=$ sedikit; $\mathrm{xx}=$ sedang; $x x=$ banyak.

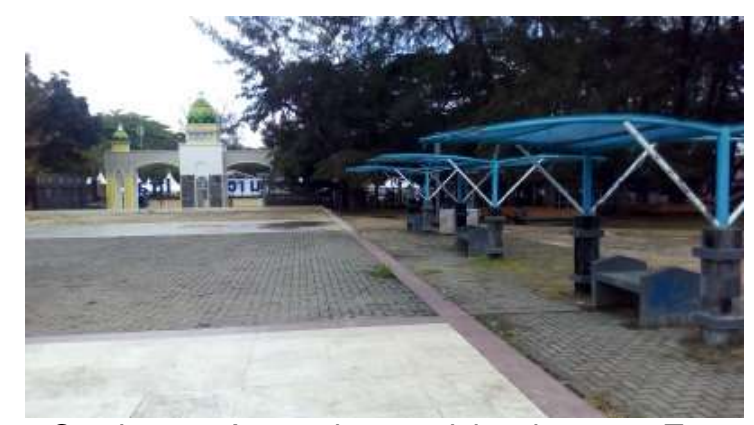

Gambar 10. Area pelataran dalam kawasan Tugu Religi didominasi hard material

\begin{tabular}{cccc}
\multicolumn{4}{c}{ Tabel 5. Indikator iklim mikro pelataran Tugu Religi } \\
\hline $\begin{array}{c}\text { Titik } \\
\text { ukur }\end{array}$ & $\begin{array}{c}\text { Kec. angin } \\
\text { (m/s) }\end{array}$ & $\begin{array}{c}\text { Tempera- } \\
\left.\text { tur }{ }^{\circ} \mathrm{C}\right)\end{array}$ & $\begin{array}{c}\text { Kelemba- } \\
\text { ban }(\% R h)\end{array}$ \\
\hline B1 & 1,8 & 33,9 & 47,2 \\
B2 & 1,825 & 34,3 & 48,275 \\
B3 & 0,875 & 33,9 & 48,95 \\
B4 & 1,475 & 33,7 & 49,05 \\
B5 & 0,6 & 35,4 & 43,975 \\
B6 & 1,175 & 36,0 & 45,025 \\
B7 & 1,1 & 35,5 & 47,275 \\
B8 & 0,95 & 36,3 & 47 \\
B9 & 0,4 & 37,6 & 40,375 \\
B10 & 0,6 & 34,8 & 44,575 \\
\hline
\end{tabular}

Nilai komponen iklim mikro yang terdiri atas kecepatan angin, temperatur, dan kelembaban udara dapat dilihat pada tabel 5 dan gambar 11. Terlihat bahwa kecepatan angin umumnya lebih kuat dibandingkan kecepatan angin pada kawasan Taman Walikota, hal ini ditandai dengan grafik kecepatan angin pada rentang nyaman hanya terdapat pada satu titik, yakni B9 dengan kecepatan angin $0,4 \mathrm{~m} / \mathrm{s}$, Sedangkan titik lainnya berada di atas angka $0,5 \mathrm{~m} / 5$. Kecepatan angin berkisar di angka 1 
$\mathrm{m} / \mathrm{s}$, bahkan beberapa titik menyentuh angka $1,8 \mathrm{~m} / \mathrm{s}$ pada daerah yang terbuka misalnya pada titik B1 dan B2.

Temperatur tertinggi adalah $37,6^{\circ} \mathrm{C}$ pada titik B9. Sedangkan yang terendah adalah $33,7^{\circ} \mathrm{C}$ pada titik B4. Nilai-nilai ini tergolong cukup tinggi, karena standar kenyamanan termal untuk indikator suhu udara di wilayah tropis berada di kisaran $20,5^{\circ} \mathrm{C}-27,1^{\circ} \mathrm{C}$. Adapun suhu udara di atas nilai tersebut dikategorikan panas dan sangat panas. Tingginya suhu udara, serigkali diimbangi dengan kondisi kadar air dalam udara atau lebih dikenal dengan kelembaban relatif. Nilai rata-rata kelembaban relatif berada di ambang nyaman dengan nilai terendah berada di angka $40 \%$ sedangkan yang tertinggi adalah $49 \%$.
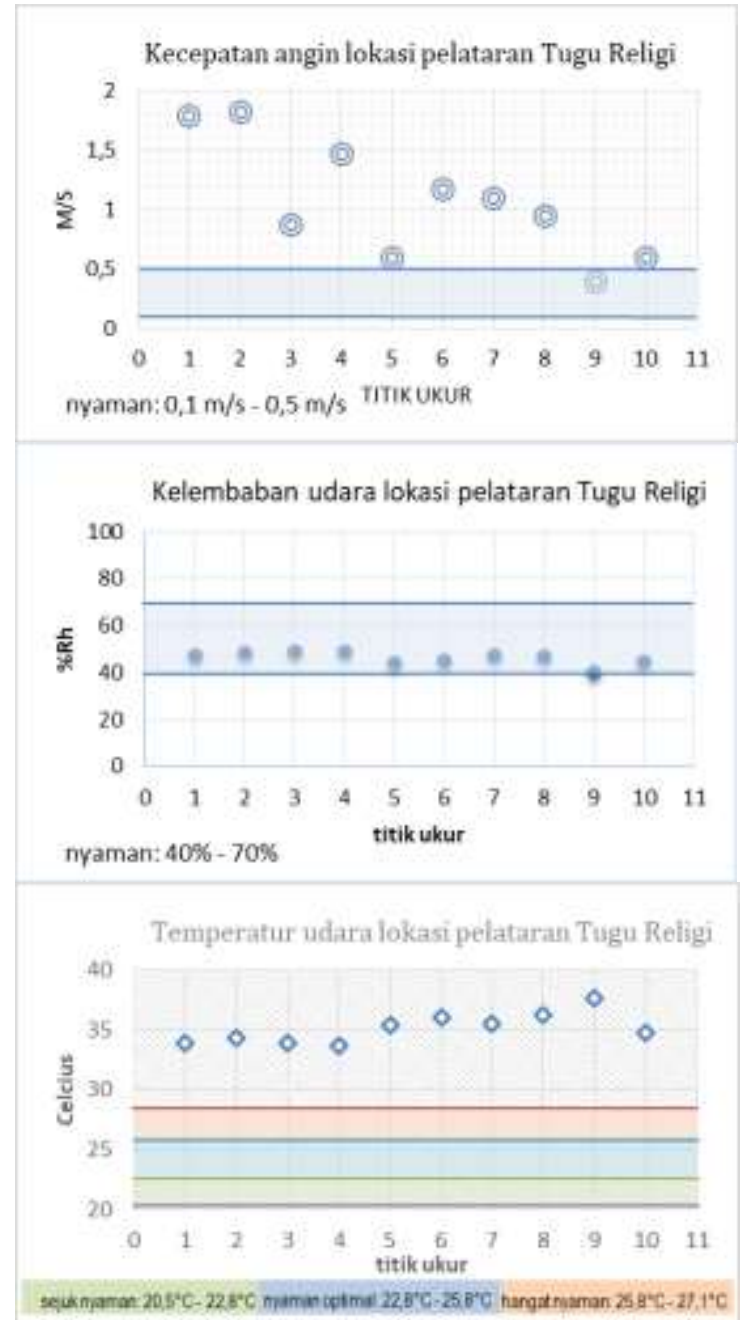

Gambar 11. Grafik nilai parameter iklim mikro lokasi pelataran Tugu Religi

\section{Perbedaan Iklim Mikro}

Perbedaan iklim mikro antara kedua kelompok ruang terbuka diuji dengan menggunakan uji statistik Corellate Independent T-Test. Hasil deskripsi statistik korelasi kelompok terhadap variabel iklim mikro yang diuji dapat dilihat pada tabel berikut.

Tabel 6. Nilai rata-rata iklim mikro

\begin{tabular}{cccc}
\hline & lokasi & $\mathrm{N}$ & Mean \\
\hline \multirow{2}{*}{ suhu udara } & tamkot & 9 & 33,5844 \\
& tugu religi & 10 & 35,1400 \\
\multirow{2}{*}{ kelembaban } & tamkot & 9 & 49,7711 \\
\multirow{3}{*}{ angin } & tugu religi & 10 & 46,1700 \\
& tamkot & 9 &, 5911 \\
& tugu religi & 10 & 1,0800 \\
\hline
\end{tabular}

Pengujian statistik Independent T-Test, digunakan untuk melihat perbedaan antara dua grup variabel. Pada penelitian ini, jumlah kelompok terdiri atas 2 yakni Taman Walikota dan pelataran Tugu Religi Sultra. Berdasarkan hasil pengujian Levene's Test for Equality of Variances, diperoleh signifikansi antara dua kelompok umumnya menunjukkan nilai yang tidak signifikan. Hal ini terlihat dari besaran nilai signifikansi ketiga indikator uji, diantaranya suhu udara nilai probabilitas adalah 0,283 dan nilai $F=1,231$; kelembaban udara nilai probabilitas adalah 0,115 dan nilai $\mathrm{F}=2,759$; kecepatan angin nilai probabilitas adalah 0,105 dan $F=2,936$. Nilai probabilitas ketiga indikator bernilai lebih besar dari 0,05 sehingga dapat disimpulkan bahwa tidak ada perbedaan yang signifikan antara dua kelompok yang diuji atau nilai variansnya sama.

Selanjutnya, pengujian Independent $T$-Test for Equality of Means atau perbedaan rata-rata digunakan untuk mendeskripsikan nilai ratarata dan perbedaan nilai variabel uji antara dua kelompok. Nilai rata-rata iklim mikro setiap lokasi ditunjukkan pada tabel. Pada indikator suhu udara, terlihat lokasi pelataran Tugu Religi Sultra memiliki nilai lebih tinggi dengan selisih $-1,555^{\circ} \mathrm{C}$ yakni $35,14^{\circ} \mathrm{C}$. Sedangkan di Taman Walikota, suhu udara rata-ratanya tercatat $33,58^{\circ} \mathrm{C}$. Nilai kelembaban udara atau persen kadar air dalam udara di Taman Walikota lebih tinggi dengan selisish 3,060\%, yakni $49,77 \%$, sedangkan pada pelataran nilainya lebih rendah yakni $46,17 \%$. Kondisi kecepatan angin antara keduanya pun berbeda, nilai rata-rata kecepatan angin pada Taman Walikota hanya $0,5 \mathrm{~m} / \mathrm{s}$, sedangkan pada pelataran Tugu Religi Sultra mencapai $1,08 \mathrm{~m} / \mathrm{s}$ atau terdapat selisih $-0,488 \mathrm{~m} / \mathrm{s}$. Berdasarkan hasil rata-rata pengukuran maka dapat ditarik kesimpulan bahwa kedua lokasi ruang terbuka pada waktu siang hari beriklim panas dan tidak nyaman. 
Pada dasarnya kondisi vegetasi dengan kerapatan tinggi dan material penutup lahan pada Taman Kota masih didominasi elemen lunak, akan tetapi angin tidak dapat masuk ke dalam kawasan karena terhalang vegetasi. Karena pada dasarnya, udara akan terus mempertahankan arah geraknya hingga menemui penghalang. Hal ini mengakibatkan udara panas yang berasal dari radiasi pada area tengah tidak dapat keluar dari kawasan. Sementara itu, pada pelataran Tugu Religi tingginya suhu udara dipengaruhi oleh kurangnya penggunaan elemen lunak/alami di kawasan. Elemen vegetasi bernilai kurang dari $50 \%$ luas kawasan. Hal ini mengakibatkan radiasi matahari masuk mengenai lahan tanpa penghalang. Sebagian besar material yang digunakan merupakan material dengan nilai albedo tinggi. Material dengan albedo atau daya reflektasi material terhadap radiasi cukup tinggi mengakibatkan penyerapan radiasi kecil sehingga daya pantul semakin besar sehingga mengakibatkan suhu udara pun meningkat.

\section{Temperature Humidity Index}

Salah satu metode analisis untuk menentukan tingkat kenyaman suatu daerah atau tempat yakni dengan menggunakan metode perhitungan Temperature Humidity Index (THI). Pada metode analisis ini, nilai temperatur ambien dan kelembaban relatif menjadi tolak ukur utama dalam penentuan nyaman atau tidaknya suatu tempat.

Tabel 7. Nilai Temperature Humidy Index

\begin{tabular}{|c|c|c|c|}
\hline Lokasi & $\begin{array}{l}\text { Titik } \\
\text { ukur }\end{array}$ & THI & Keterangan \\
\hline \multirow{9}{*}{$\begin{array}{l}\text { Taman } \\
\text { Walikota }\end{array}$} & $A 1$ & 30,73 & sangat tidak nyaman \\
\hline & $A 2$ & 30,03 & tidak nyaman \\
\hline & A3 & 30,11 & tidak nyaman \\
\hline & A4 & 30,38 & tidak nyaman \\
\hline & $A 5$ & 31,90 & sangat tidak nyaman \\
\hline & $A 6$ & 30,45 & tidak nyaman \\
\hline & $A 7$ & 28,75 & nyaman \\
\hline & A8 & 29,78 & tidak nyaman \\
\hline & A9 & 29,76 & tidak nyaman \\
\hline \multirow[t]{5}{*}{ Rata rata } & & 30,21 & tidak nyaman \\
\hline & $B 1$ & 30,32 & tidak nyaman \\
\hline & $B 2$ & 30,75 & sangat tidak nyaman \\
\hline & B3 & 30,44 & tidak nyaman \\
\hline & $B 4$ & 30,27 & tidak nyaman \\
\hline Pelataran & B5 & 31,43 & sangat tidak nyaman \\
\hline \multirow[t]{5}{*}{ Tugu Religi } & $B 6$ & 32,04 & sangat tidak nyaman \\
\hline & $B 7$ & 31,76 & sangat tidak nyaman \\
\hline & $B 8$ & 32,45 & sangat tidak nyaman \\
\hline & $B 9$ & 33,12 & sangat tidak nyaman \\
\hline & $B 10$ & 30,94 & sangat tidak nyaman \\
\hline \multicolumn{2}{|l|}{ Rata rata } & 31,19 & sangat tidak nyaman \\
\hline
\end{tabular}

Nilai Temperature Humidity Index (THI) pada kedua kawasan pada waktu pengambilan data siang hari dengan kondisi langit cerah menunjukkan data yang bervariasi pada semua titik ukur baik pada Taman Walikota maupun Pelataran Tugu Religi Sultra (tabel 6 dan gambar 11). Nilai THI terendah pada lokasi Taman Walikota tercatat sebesar 28,75 yakni pada titik ukur A7 dan yang tertinggi adalah titik A5 dengan nilai 31,90. Nilai THI pada titik A7 masuk pada kriteria nyaman, sedangkan nilai $\mathrm{THI}$ pada titik A5 tergolong pada kriteria sangat tidak nyaman. Titik $A 7$ merupakan titik ukur dengan nilai suhu udara terendah dibandingkan titik lainnya yakni $32,06^{\circ} \mathrm{C}$. Hal ini berarti tatanan vegetasi pada titik ini cukup efektif dalam mempengaruhi iklim mikro. Sementara itu, titik A5 terletak tepat di tengah areal taman. Pada titik A5, kecepatan angin rata-rata tercatat rendah, yakni $0,4 \mathrm{~m} / \mathrm{s}$. Angin kurang berhembus pada titik ini karena posisi titik yang tidak memungkinkan angin berhembus lebih kencang. Angin yang bertiup dari luar kawasan tertahan oleh vegetasi bertajuk lebar dan tingkat kerapatan tinggi yang ditempatkan di sekeliling areal Taman Walikota. Lebih lanjut, faktor yang menjadikan nilai THI cukup tinggi adalah suhu udara. Suhu udara pada titik tersebut tercatat lebih tinggi dibandingkan titik amatan lainnya yakni $35,6^{\circ} \mathrm{C}$, hal ini dikarenakan pantulan radiasi tinggi dan suhu panas yang terkurung di sekitar titik ukur, atau pada area titik A5.

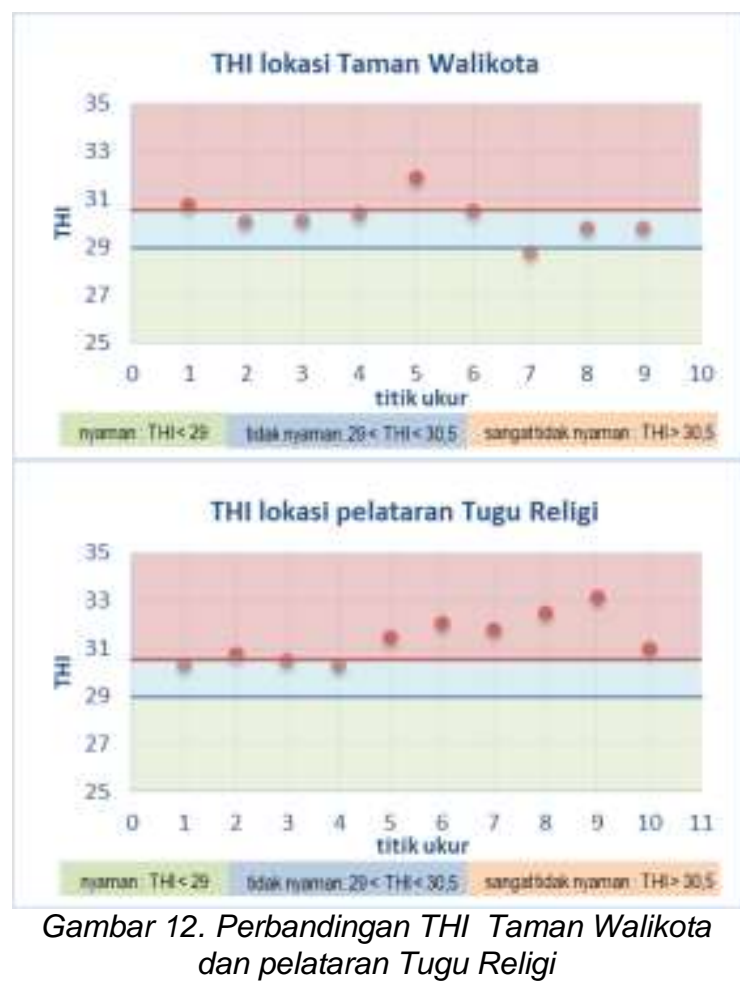

Pada lokasi terpisah, nilai rata-rata $\mathrm{THI}$ pada kawasan pelataran Tugu Religi Sultra tercatat lebih tinggi dibandingkan kawasan Taman 
Walikota. Dari 10 titik ukur, terdapat 7 titik ukur yang tergolong ke dalam kriteria sangat tidak nyaman, sedangkan 3 titik ukur lainnya berada pada kategori tidak nyaman. Nilai THI tertinggi tercatat sebesar 33,12. Nilai ini sangatlah tinggi. Nilai THI ini diperoleh pada titik ukur B9, yakni pada titik ukur dengan rata-rata temperatur tertinggi. Faktor utama yang mempengaruhi tingginya $\mathrm{THI}$ pada kawasan pelataran Tugu Religi adalah tingginya suhu udara. Hal ini dipengaruhi oleh minimnya vegetasi sehingga filter radiasi kurang optimal serta penggunaan penutup permukaan tanah yang bersifat reflektif terhadap radiasi.

Berdasarkan nilai rata-rata THI kedua lokasi, sebaiknya pengunjung mengurangi aktivitas fisik pada siang hari karena rata-rata indikasi THI berada pada kriteria tidak nyaman dan sangat tidak nyaman. Hanya saja, pada Taman Walikota masih memungkinkan adanya aktivitas ringan hanya pada titik titik tertentu yang terpantau nyaman. Sedangkan pada area pelataran Tugu Religi, hasil THI menunjukkan kriteria sangat tidak nyaman. Oleh karena itu pengunjung di pelataran Tugu Religi sebaiknya menghindari aktivitas pada siang hari.

\section{KESIMPULAN}

Dari penelitian ini diperoleh kesimpulan sebagai berikut:

1. Nilai paramater Iklim mikro siang hari di kedua lokasi ruang terbuka di Kota Kendari yakni Taman Walikota dan pelataran Tugu Religi Sultra umumnya di atas standar kenyamanan untuk indikator suhu udara dan kecepatan angin, sedangkan indikator kelembaban relatif masih berada di ambang nyaman.

2. Berdasarkan analisa statistik, kondisi iklim mikro di Taman Walikota lebih baik dibandingkan pelataran Tugu Religi. Pada dasarnya kedua lokasi memiliki karakteristik tutupan lahan dan luasan elemen vegetasi berupa pohon yang berbeda pula. Akan tetapi menurut pengujian statistik menunjukkan perbedaan yang kurang signifikan yakni: suhu udara (sig. $=0,283$ ); kelembaban relatif (sig. $=0,115$ ); dan kecepatan angin (sig. $=0,105)$. Hal ini diakibatkan komposisi vegetasi dan penggunaan material keduanya yang berbeda.

3. Nilai kenyamanan thermal kedua lokasi dengan analisis Temperature Humidity Index (THI) umumnya berada pada kategori tidak nyaman dan sangat tidak nyaman. Pada Taman Walikota nilai THI terendah 28,75, tertinggi 31,90, dan ratarata 30,21 (tidak nyaman). Sedangkan pada pelataran Tugu Religi, nilai THI terendah 30,27 , tertinggi 33,12 , dan ratarata 31,19 (sangat tidak nyaman). Berdasarkan hasil analisa THI maka tidak dianjurkan untuk beraktivitas fisik di kedua lokasi pada siang hari, khususnya pada pelataran Tugu Religi.

\section{UCAPAN TERIMA KASIH}

Penelitian dan penulisan karya ilmiah ini terselenggara atas atas bantuan dana penelitian Fundamental (Penelitian Dasar Unggulan Perguruan Tinggi) tahun anggaran 2017 dengan nomor kontrak 627/UN29.20/PPM/2017.

\section{DAFTAR PUSTAKA}

[1] Badan Pusat Statistik. (2017). Kota Kendari dalam Angka 2017. Kendari: Badan Pusat Statistik Kota Kendari.

[2] Voogt, J.A. (2002) Urban Heat Island. In: Munn, T., Ed., Encyclopedia of Global Environmental Change, Wiley, Chichester, Vol. 3, 660-666.

[3] Peraturan Menteri Pekerjaan Umum No; 05/PRT/M/2008 tentang Pedoman Penyediaan dan Pemanfaatan RTH di Kawasan Perkotaan, Jakarta: Kementerian Pekerjaan Umum.

[4] Sangkertadi. (2013). Kenyamanan Termis di Ruang Luar Beriklim Tropis Lembab. Bandung : Alfabeta.

[5] Hakim, R., \& Utomo, H. (2004). Komponen Perancangan Arsitektur Lansekap: Prinsip - Unsur dan Aplikasi Disain. Jakarta: Bumi Aksara.

[6] Karyono, T. H. (2010). Green Architecture: Pengantar Pemahaman Arsitektur Hijau di Indonesia. Jakarta: Rajawali Press.

[7] Olgyay,V. (1963). Design with Climate: Bioclimatic Approach to Architectural Regionalism. Princetown: Princetown University Press.

[8] Holton, J. R. (2004). An Introduction to Dynamic Meteorology. Burlington: Elsevier.

[9] Lippsmeier, G. (1994). Bangunan Tropis. Jakarta: Erlangga.

[10] Soegijanto. (1998). Bangunan di Indonesia dengan Iklim Tropis Lembab Ditinjau dari Aspek Fisika Bangunan, Jakarta: Direktorat Jenderal Pendidikan 
Tinggi Departemen Pendidikan dan Kebudayaan.

[11] Frick, H. \& Darmawan, A. (2007). IImu Fisika Bangunan. Jogjakarta: Kanisius

[12] Thom, E. C. (1959). The Discomfort Index. Weatherwise, 12(2), 57-61.

[13] Nieuwolt S. (1977). Tropical Climatology. London: Wiley.

[14] Sugiasih. (2013). Rumus Indeks Ketidaknyamanan Suatu Wilayah. Jurnal Fourier. Vol. 2, No. 1, 19-25.

[15] Frick, H. \& Suskiyatno, B. (1998). DasarDasar Eco-Arsitektur. Kanisius: Yogyakarta. 
